\section{From Latin American International Political Economy to Latin American Global Political Economy}

Da Economia Política Internacional Latino-americana à Economia Política Global Latino-americana

\section{De Economía Política Internacional Latinoamericana a Economía Política Global Latinoamericana}

\author{
Ernesto Vivares ${ }^{1}$ \\ Raúl Salgado²
}

D0I: 10.5752/P.2317-773X.2021v9.n2.p7

Received in February 18, 2020

Accepted in August 02, 2020

\begin{abstract}
This paper focuses on the differences between International Political Economy (IPE) versus Global Political Economy (GPE) in Latin America. It explores how IPE tends to be taught and researched beyond mainstream IPE but in dialogue with it. It engages with the main literature of this field to discuss the contours and extension of a transition in teaching and research. It rests upon a historical sociological approach and employs a qualitative analysis of syllabi and curricula of various masters and doctoral programs on International Relations/Studies and underlying disciplines, and is complemented with semi-structured interviews with leading scholars of IPE from across the region. The paper argues that there is a shift from mainstream IPE to a new Latin American GPE as the result of a revitalization of the field and as a response to the new regional and global challenges. New dynamics of development, conflict and a changing world order coexist with old problems, pushing our field to find new responses, demonstrating the limits of the traditional knowledge, and requiring the development of new contributions. While the shift may be minor, it is constant and steady, and is neither homogenous nor dominated by a unique vision of the field, but it is defined by heterogeneity and plurality.
\end{abstract}

Keywords: Latin American IPE, GPE, Teaching and Research

\section{RESUMO}

Este artigo aborda as diferenças entre Economia Política Internacional (EPI) e Economia Política Global (EPG) na América Latina. Explora-se o modo pelo qual a EPI é ensinada e pesquisada, transcendendo a EPI convencional, mas em debate com ela. Dialoga-se com literatura mais importante desta área para discutir os contornos e a extensão de uma transição no ensino e na pesquisa.
1. Ernesto Vivares is Professor in International Political Economy at FLACSO Ecuador, Master from Birmingham University and PhD from Sheffield University in UK. His research focus on Global and Regional Political Economy, South America, Development and Conflict. ORCID 0000000221361089

2. Raul Salgado Espinoza is a full-term professor and researcher of foreign policy, political thought and qualitative methods at the Department of International Studies and Communication, FLACSO Ecuador. He holds a Ph.D. in Political Science and International Studies from the University of Birmingham, UK. ORCID: 0000-0002-1540-5583 
Baseia-se em uma abordagem sociológica histórica e emprega uma análise qualitativa dos currículos de vários programas de mestrado e doutorado em Relações Internacionais/Estudos Internacionais e disciplinas subjacentes; é complementado com entrevistas semiestruturadas com estudiosos de EPI da região. O artigo argumenta que há uma mudança da EPI convencional para uma nova EPG latino-americana, como resultado de uma revitalização do campo e como uma resposta aos novos desafios regionais e globais. Novas dinâmicas de desenvolvimento, conflitos e mudanças da ordem mundial coexistem com velhos problemas, levando o nosso campo a elaborar novas respostas, demonstrando os limites do conhecimento tradicional e exigindo o desenvolvimento de novas contribuições. Embora a mudança possa ser menor, é constante e estável, e não é homogênea, nem é dominada por uma visão única do campo, mas é definida pela heterogeneidade e pluralidade.

Palavras-chave: EPI latino-americana; EPG; Ensino e pesquisa

\section{RESUMEN}

Este artículo se enfoca en las diferencias entre Economía Política Internacional (EPI) versus Economía Política Global (EPG) en América Latina. Explora las tendencias en la enseñanza e investigación más allá de la EPI del mainstream, pero en conversación con ésta. Dialoga con la literatura más relevante de esta disciplina para discutir los entornos y extensión de una transición en la enseñanza e investigación. Se apoya en un enfoque histórico social y emplea un análisis cualitativo de sílabos y mallas curriculares de programas de maestría y doctorado en Relaciones/Estudios Internacionales y disciplinas subyacentes que es complementado con entrevistas semi-estructuradas a académicos especialistas en EPI de la región. El paper propone que se evidencia un cambio desde la EPI del mainstream hacia una nueva EPG latinoamericana que ha surgido como resultado de una revitalización de esta disciplina y como respuesta a los nuevos retos regionales y globales. Nuevas dinámicas del desarrollo, conflicto y de un orden global cambiante coexisten con viejos problemas y han empujado a nuestra disciplina a encontrar nuevas respuestas, demostrando los límites del conocimiento tradicional, y demandando el desarrollo de nuevas contribuciones. Si bien, el cambio puede ser menor, es constante y estable, y no es ni homogéneo ni está dominado por una única visión de la disciplina, pero está definida por la heterogeneidad y pluralidad.

Palabras claves: EPI latinoamericana, EPG, enseñanza y aprendizaje

Introduction

This paper critically analyses key research contributions concerning how teaching and research is done the field of International Political Economy (IPE) in Latin America and tackles elements of scholarly interest for recent developments of the field in the region. It encompasses the diverse ontological and epistemological approaches that show the reciprocal and dynamic power interactions between politics and economics, development and conflict, and the domestic and international spheres. The main assumption explored here is that the field is experiencing a revitalization mainly towards a global orientation of the regional field as some scholars have shown (HELLEINER, 2015; HOBSON, 2013; TUSSIE, 2018; 2020). The work highlights the scope and limitations within the field, in terms of bringing new insights to the comprehension of Latin American International Political Economy (LAIPE) beyond the Anglo- 
-Saxon IPE approaches, and refers to the means of engaging in a conversation with other IPEs as well as the mainstream (ACHARYA, 2011; COHEN, 2019). This analysis argues that there is an increasing shift from mainstream LAIPE to a Latin American Global Political Economy (LAGPE), which are clearly defined by recent contributions (TUSSIE, 2020). All the empirical evidence of the paper is based on the research done by Salgado and Vivares (2019).

Several studies have identified the different ontological and epistemological orientations, dialogues, and gaps within the field of IPE, although most of them have focused on how IPE is produced and reproduced in the Anglo-Saxon and Western world (LAKE, 2013; MALINIAK et al., 2011; MALINIAK; TIERNEY, 2009; SEABROOK; YOUNG, 2017). This focus has changed in the last decade also in Latin America. IPE, both in the North and the South, has witnessed an insightful revival beyond mainstream IPE (HELLEINER, 2015; KEOHANE, 2011; RAVENHILL, 2017; TUSSIE, 2018). This paper suggests that two central elements underlie this change. On the one hand, new dialogues and inquiries about unforeseen economic global and regional phenomena like global political economic issues such as the global pandemic, crises of the welfare national systems, massive informal migration, international trafficking, illegal commerce across borders, among others surpass the old mission and tools of mainstream IPE, which have turned to be central in the discussion and investigations of IPE in the region. These include the vulnerability of societies to the current global pandemic, drug trafficking, forced displacement, rise of nationalism and populism, the fragmentation of the Europe Union, the technological revolution, the expansion of national treats, and the decline of the liberal order. On the other hand, global factors such as the decline of the liberal order, the rise of inequality, social and environmental crises, and the return of nationalism and xenophobia have become the centre of analysis of the new wave of research contributions. As a result, the revitalisation of the field has brought about differentiation, and there, IPE has become a heterogeneous field of perspectives and inquiries that range from the English-speaking IPE discipline to the varied GPE interdisciplinary. However, the two extremes of the same debates have something in common: the quest for exploring how the struggle for power and wealth bring about development and conflict, in the context of the intersections of international-domestic, state-market, regional-global, and formal-informal realities of unequal development.

This argument stems from different contributions and a mayor study of how RRII is currently taught and researched in Latin America, which is where the study of IPE derived. It focusses on the diverse and varied practices of teaching and research in the field, highlighting weaknesses, limitations, and the different approaches to interpret the LAGPE. Therefore, this research, methodologically draws upon a qualitative research concerning the state of teaching methodology for research in IR and IPE within Latin America. It is based on the interpretation of semi-structured interviews with scholars of IPE in Latin American universities and the analysis of academic bibliography of Latin American IPE have contributed to strengthen this argument. Moreover, it reports on a survey of 540 
scholars in the different IR-subfields, 40 of whom are lecturers in methodology at postgraduate degree level (SALGADO; VIVARES, 2019). In addition, it draws on an analysis of 70 curricula and syllabi from masters and doctoral programmes from universities in 15 Latin American states, including Argentina, Brazil, Mexico, Colombia, Chile, and Ecuador, among others, and the editorial boards of the main academic journals IPE globally (SALGADO; VIVARES, 2019). In this sense, this research has a qualitative and descriptive orientation and is driven by analytical and theoretical insights provided by our and other similar investigations both in the field of IR in the region and abroad. This investigation aims to complement other contributions such as Tussie (2018), Trownsell et al. (2019), and Madeiras et al. (2016), which have also been central in framing and deepening the analysis of a change in the approaches to IR and its sub-fields. Therefore, this paper seeks to help to identify the different perspectives that make up LAIPE in the region by taking into account the use of diverse theoretical approaches in the field, as well as the emerging contradictions and limitations around the debates in this fast-growing regional academic arena. The paper is organised into three parts. It begins by outlining the major IPE perspectives. Secondly, it explores the central components of the concept of Latin American IPE, to evidence that today scholars are producing research that support the idea of a LAGPE. Finally, the conclusion highlights the importance of plurality, transdisciplinarity, and Global South issues as part of the research agenda of a LAGPE.

Mainstream IPE tends to be pluralist but still dominated by Anglo-Saxon approaches

Beyond the diverse orientations of IPE, there is one central idea common between them: the promise of new insights as a result of research, seeking to understand the role of power in the interactions between politics and economics, the international and domestic, and development and conflict in different locations within a historical global order. In other words, about the development and conflict in their most general expression, outcomes.

In the main, IPE research is done from different perspectives, but is still dominated by the trichotomous (Realism, Liberalism and Marxism), the Open Economic Policy (OEP), and the North American-British. These views are supplemented by the concept of global conversations, GPE, post-development and poststructuralism to mention but a few. All these represent the general global map of epistemic communities, factions, or clusters where diverse IPEs are developed, contested, or adapted. These new tendencies clearly go beyond mainstream focus (COHEN, 2019; HELLEINER, 2015; MIGNOLO, 2016; SEABROOK; YOUNG, 2017).

From these conversations and debates, we can identify three main academic issues regarding mainstream views. The first suggests that classrooms are the source of reproduction of these divisions and partisanship in the field, both in the South as well as in the North (SEABROOK; YOUNG, 2017). Many academic programmes from the Latin American region and beyond, teach and train young scholars in one of those divisions. 
These divisions are generally perspectives developed within the Anglo-Saxon, mainly the North American-British, and European academic world. This focus on one view frames and generates a partisan orientation of their academic performance and limits the development of the field (HOBSON, 2013). Secondly, the design of academic training tends to yield methodological biases at the time research is done, as the dominating views are based on formal realities of the Western development (CARVALHO; GIL-PEREZ, 2011). Hence, it limits the economic realities, research perspectives and methodological developments of other regions. Thirdly, the two factors highlighted above represent real obstacles to moving mainstream IPEs towards a GPE in order to deal with and respond to the new global scenarios of power and developments, which thirty years ago, when mainstream IPE was designed, were unforeseeable.

Mainstream IPE was developed for an expanding liberal world order and civilization, not for a declining liberal system. It did not take into account either for the rise of South East Asia, nor was it equipped to explain new events such as the shift within the United States (USA) and Europe to xenophobia and nationalism, the social disillusionment with democracy and free markets, social deprotection, migration and humanitarian crises, and environmental destruction without scale. These all are interrelated facts that mirror global and fundamental transformations. Indeed, the grounding principles of mainstream IPE in its response to academic questions relate to the transformation of the old liberal order and its issues such as complex interdependence, interstate relations, hegemony, free trade, regimes, liberal institutions, and others. However, today these pillars of mainstream IPE continuously evaporate into the air as new severe concepts appear, such as global power transitions, exodus, racism, environmental catastrophes, development and conflict, cyber wars, nationalism, parasitarian capitalism, and terrorism, amongst others. Most of these have a global connotation with regional characteristics. Therefore, a new and comprehensive GPE is compelled to enclose old and new issues of the international political economy, as well as new methodological approaches and theoretical perspectives of the discipline of IPE.

What is considered GPE? The answer varies according to the ontological and epistemological position taken by colleagues and their contributions. It takes various paths, depending on whether GPE is viewed as a normative, scientific, reflectivist, alternative discipline or research enterprise (RAVENHILL, 2017). Seabrook and Young (2017), for instance, surveyed the field with a central focus in the Western World. Their work maps its varied communities and orientations concerning teaching, researching, and publishing in a respectful academic format although not global. They found that beyond the (North) American-British schools and debates, there are other divides in the Western field. They suggest that there are between five and seven communities, epistemic networks, or clusters of IPE scholars. And as a matter of their evidence, there are clear distinctions between how they teach, research, and publish on IPE (SEABROOK; YOUNG, 2017). However, GPE encloses these new phenomena within present international political economy in its research 
agenda, as well as new methodological and theoretical approaches, which make it more inclusive and pluralistic. IPE and GPE are connected, but are not the same, and they even become more different with its regional extensions as they are defined by more regional features. The orientations and differences between IPE and GPE are basically outlined here in the chart below.

Table 1 - Contrasting features of IPE and GPE

\begin{tabular}{|l|l|l|}
\hline & $\begin{array}{l}\text { International Political Economy } \\
\text { IPE }\end{array}$ & $\begin{array}{l}\text { Global Political Economy } \\
\text { GPE }\end{array}$ \\
\hline $\begin{array}{l}\text { Ontological focu- } \\
\text { ses and sources }\end{array}$ & $\begin{array}{l}\text { Western world. } \\
\text { Focused on Global Liberal Order. } \\
\text { Formal Order, Institutions and Economic Dynamics. }\end{array}$ & $\begin{array}{l}\text { Development and Conflict in Western and Non-Western World. } \\
\text { Focused on Global-Regional-National dynamics. } \\
\text { Formal - Informal Order, Institutions, Economic, and Conflicts. }\end{array}$ \\
\hline $\begin{array}{l}\text { Epistemic } \\
\text { networks }\end{array}$ & $\begin{array}{l}\text { Varied foci mainly network-related and located in Wes- } \\
\text { tern world. } \\
\text { Self-legitimated and referenced. } \\
\text { Dominant Rational-Choice communities. }\end{array}$ & $\begin{array}{l}\text { Regional located. } \\
\text { Growing in dialogue with IPE. } \\
\text { Legitimation subordinated to dependence of Western epistemic } \\
\text { communities' approval. } \\
\text { Interdisciplinary dynamic fields. }\end{array}$ \\
\hline Aims & $\begin{array}{l}\text { To comprehend the rise, expansion, and failures of the } \\
\text { Global Liberal Order to solve them. }\end{array}$ & $\begin{array}{l}\text { To comprehend the Global Political Economy of Development and } \\
\text { Conflict in Times of Changes, Crises and Transition }\end{array}$ \\
\hline Ontological axes & $\begin{array}{l}\text { International-Domestic, } \\
\text { State-Market, } \\
\text { Agency-Structure. }\end{array}$ & $\begin{array}{l}\text { Complex Ontologies subordinated to Space-Time and research focus. } \\
\text { Development-Conflict. } \\
\text { Regional-Global. Formal-Informal Development. Identity-Development. }\end{array}$ \\
\hline $\begin{array}{l}\text { Epistemology } \\
\text { Liberalism, Realism, Constructivism, Traditional Marxism. }\end{array}$ & $\begin{array}{l}\text { IPE traditions, plus History, Geography, Technology, and others new } \\
\text { research fields and approaches. }\end{array}$ \\
\hline Methodology & $\begin{array}{l}\text { From Positivist dominance but also up to Reflectivist. One } \\
\text { Research Agenda, Homogenous Methodologies. Schools. }\end{array}$ & $\begin{array}{l}\text { Theoretical Pluralism and Eclectic Methodology. Range from Positivist } \\
\text { to Reflectivist, Post Structuralist nd Critical Conflict approaches. }\end{array}$ \\
\hline $\begin{array}{l}\text { Teaching and } \\
\text { Learning }\end{array}$ & $\begin{array}{l}\text { Focus on Schools and Western History } \\
\text { Research oriented and Regionally differentiated }\end{array}$ \\
\hline
\end{tabular}

Sources: design by the authors

From Latin American International Political Economy to Latin American Global Political Economy

In Latin America, the reality of the field is not so much different but framed and oriented in relation to its academic history and today features (DECIANCIO, 2018; TUSSIE, 2018). To start, if we compare the results between the top international sales and the most recommended handbooks in the syllabi most used at postgraduate level, based on a large sample of departments in International Relations/International Political Economy, it is possible to see how LAIPE (the traditional version) is taught. To advance the analysis, we look firstly at how LAIPE has been taught outside the region, within the English-speaking world, and then, we analyse teaching and research IPE within Latin America (SALGADO; VIVARES, 2019).

The first formats of teaching LAIPE outside the region start with the traditional ahistorical and essentialist ontological division among liberalism, nationalism, and marxism (or sometimes constructivism), following a format of the books of Gilpin (1987) and O'BRIEN and WILLIAMS (2016). In line with the observations of Cohen (2014), the second 
syllabi's formats are focused on the so-called [North] American Open Economic Policy (OEP), with its emphasis on rational choice, institutionalist, and formal economics (FRIEDEN; LAKE, 1999; KRUGMAN; OBSTFELD, 2005; LAKE, 2009; OATLEY, 2013). The third format of teaching, which still guides some scholars, is related to the shift introduced by Cohen (2014), with the situated ontology of the [North] American vs. British schools (RAVENHILL, 2017; SEABROOK; YOUNG, 2017). ${ }^{3}$

In 2009, John Ravenhill's contribution gave way to another format by modifying the ontological and epistemological axis of the debate. Therefore, Ravenhill (2009) argued that rather than a discipline, IPE had better be considered as a field of inquiry. In this context, Ravenhill $(2005)^{4}$ suggested that the field should move from the traditional IPE to a GPE, due to the missing junctures of research in-between dual conceptions and dividing perspectives. Developing further dialogue, later Mark Blyth (2009) introduced the constructivist mediator concept of the global conversation, opening teaching to an umbrella that might include the holy troika, the [North] American/British schools and the quantitative/qualitative divides in the field. Despite the innovation, the field of IPE is still an Anglo-Saxon arena, and LAIPE there continued to be interpreted as only the past glories of the Dependency Theory and Developmentalism, referenced with the same repeated voices (i.e. PALMA, 2009).

In this general framework, it is possible to see how English-speaking and Western IPEs have framed and taught LAIPE: commonly as packages of perspectives frozen in time, deploying a linear sequence of thinkers' ideas and concepts related to the golden age of contributions made by regional IPE, during the time of regional responses to Developmental Capitalism and the Cold War (COX, 2002). A mixture of economic theory with static political images of the region has been taught, in which realist appears at the top and is followed by institutionalist and formal perspectives. Syllabi tend to present the old perspectives of Cepalian Developmentalism, Dependency Theory, and in the best cases of the $90 \mathrm{~s}$, as the unique contributions from the region (COHEN, 2019). The sequence commonly starts with the names of Raul Prebisch (sometimes presented as one of the founding fathers of Dependency Theory), Albert Hirschman, Gunder Frank, Enrique Cardoso, Enzo Faletto and others-the thinkers of the unique age of the traditional LAIPE up to the beginning of the neoliberal stage of the 90 s.

In addition, in the English-speaking teaching of IPE today, the contributions of LAIPE are the concepts and theoretical elements developed during the 1960s, 1980s, and sometimes in the 1990s, which leave out the tendencies and research of the last two decades (LEITERITZ; RIAÑO, 2018; TUSSIE, 2018;). In this way traditional IPE does not take into account the regional contributions concerning how ideas and the region, in different historical periods and world orders, confront hegemonic approaches, study power configurations, international and domestic links, regions and multilateral crafts of development and conflict (HELLEINER, 2017; TUSSIE, 2018).

Similar biases and problems can be found in the development of IPE at a global level. This could be because IPE history did not begin in
3. Nonetheless, later Cohen would deepen that with the inclusion of other Anglo-Saxon contributions such as the (North) America 'Left Out', the Canadian and Australian 'Far Outs' (2014). Something again extended by Cohen lately in his book Advanced Introduction to International Political Economy (2019).

4. Thus, IPE distinguishes itself by ontological and epistemological diversities, focusing on the interrelations between public and private power, and in the allocation of scarce sources, to see who gets what, when and how. Briefly, Ravenhill opened the middle space in the divide, although still tightening the notion of IPE research to formal IPEs, in other words the relationship between formal politics and economics (2005). 
the Western world nor in Latin America. Indeed, there are many IPEs, many of which can be traced back to a period in previous centuries (HELLEINER, 2017; HOBSON, 2013). Certainly, in recent decades the discipline has moved towards a significant self-reflection concerning its Western, ahistorical, and universalist Anglo-Saxon ontologies and epistemologies. This process opens up debates about its globalisation and frontiers, and has created spaces for teaching and research in the contexts of the global economic and political phenomena (AGNEW, 1994; AMIN, 1988; CAFRUNY, 2016; GROSFOGUEL 2009; GROSFOGUEL; CERVANTES-RODRIGUEZ, 2000; HELLEINER, 2017; HOBDEN; HOBSON, 2002; SHAW et al., 2019). Accordingly, fundamental contributions to IPE come from alternative perspectives to IPE which focus on the vacuums in the mainstream field such as the areas of history, sociology, gender, de-colonial theory, trade, and governance. For instance, using an historical-sociological approach, John Hobson, and other scholars, identify the Eurocentric and ahistorical ontologies and epistemologies fostering the significant myths or conceptual cages as a marking character of teaching and research in Western IPE (ASHWORTH, 2002; HOBSON, 2013).

Feminist studies have perhaps produced the most advanced contributions to the field given their pluralist ontologies and research, which have served to frame inequality and hierarchies within time and space beyond universalisms and ahistoricisms. It encompasses a comprehension of women's agency and of the structural conditions they live in, as how they relate to power, inequality, and violence. These views challenge IPE's western liberal assumptions (MADHOK; SHIRIN, 2012; MAHMOOD, 2005; PARPART; PARASHAR, 2018). Paradoxically, in Latin America, despite the vital presence of feminist scholars today, its scholarly work is instead led mostly by sociological, anthropological, postcolonial feminist studies (ELIAS, 2013; LUXTON, 2018). Consequently, the most recent critiques to mainstream IPE came from de-colonial studies, focusing on the misleading framework of universalist and essentialist epistemologies based on Western universal rationality (GROSFOGUEL 2009, 2006; GROSFOGUEL and CERVANTES-RODRIGUEZ, 2000; MALIK, 2014. Decolonialism argues for a pluriverse or a variety of ways of knowing which adhere to diverse historical and geographical experiences (MIGNOLO, 2018). Hence, de-colonial studies in IPE have proved to be a growing field in the region, both in teaching and research. Notwithstanding this, it still lacks fluid dialogue with other approaches.

In Latin America, IPE tends to be taught mostly as a traditional discipline, based on one of the divides mentioned above, focusing on a mixture of old regional traditions with Anglo-Saxon approaches, although in some cases with innovative formats particularly in Argentina, Brazil, Colombia, and Ecuador (SALGADO; VIVARES, 2019). Introductions to IPE are presented either as bodies of theories or schools, such as the most relevant traditional approaches (liberalism, realism and marxism), economics versus politics - (North) American versus British schools - or tied to the old traditions of the developmentalist 
and dependency theory with a strong focus on political sciences such as rational choice, formal economics, and institutions. New research-oriented syllabi instead, which have a small representation, are generally concentrated in the field of constructivist, radical, critical and feminist IPEs of globalisation, development, gender, race or class. Some of the authors have joint the Union for Radical Political Economics (URPE). In this context, various types of formats of teaching and research IPE in the region can be identified. Each of these possess a dominant image of what Latin American IPE is, how their global dialogues are intertwined and how they are related to the top-ranked handbooks in the field.

The way that each one of these IPE perspectives approaches Latin American scholarship in Western world varies according to their ontological and epistemological orientations of them; however, visibility of the regional contributions is generally absent. The English-speaking approaches presented above, however, share a common factor: LAIPE accounts for previous vigorous and significant contributions of economic structuralism and dependency theory, but exclude present approaches (BLYTH, 2009; COHEN, 2019; O’BRIEN; WILLIAMS, 2016). For the polar division between North American and British schools, LAIPE is "a tale of lost vitality" where "like Canadians, Latin Americans seem divided between an older intellectual tradition and the siren call of a newer [North] American style" (COHEN, 2019, p. 26). There, LA is presented ontologically as a type of unit or system that is uniform; analysed as being detached from the international sphere, internally struggling between inequality and political-economic instability, generally for political corruption. The region is approached through the formal lenses of the mainstream IPE, focused on trade, finance, infrastructure, multilateralism, institutions, and cooperation, in other words, traditional and top-down approaches (BLYTH, 2009). However, that only constitutes half of the regional realities, many other issues, such as development and conflict, global insertions, inequality, technological change, covert world, informal economy, and others are not on the radar of mainstream analysis.

Still, it is remarkable to see that strands of alternative or critical IPEs, including global, non-universalist, and non-historical approaches are increasing and hold contributions that have not yet entered into dialogue with mainstream regional academy (SALGADO; VIVARES, 2019). Undeniably, this research has brought about substantial innovations in teaching and research, as they are based on new ontologies and epistemologies highlighting the current faces of development and conflict, formal and informal realities, and social identities from the bottom, representing a critical dialogue with western IPEs (GROSFOGUEL, 2006; GUDYNAS, 2012). However, despite these new contributions, Westernism, nationalism, and language are still the primary structural barriers of the IPE communities. Factions, networks, and clusters, present themselves in the dominant ways of teaching, researching, and publishing in the field. The features and differences between LA IPE and LA GPE are basically outlined here in the chart below. 
Table 2 - Contrasting features of LA IPE and LA GPE

\begin{tabular}{|c|c|c|}
\hline & $\begin{array}{l}\text { Latin American } \\
\text { International Political Economy } \\
\text { IPE }\end{array}$ & $\begin{array}{l}\text { Global Political Economy } \\
\text { GPE }\end{array}$ \\
\hline $\begin{array}{l}\text { Ontological focu- } \\
\text { ses and sources }\end{array}$ & $\begin{array}{l}\text { Generally, in conflict or subordination to Anglo-Saxon } \\
\text { Schools. } \\
\text { Focused on Peripheral Regional relationship with Inter- } \\
\text { national Liberal Order during Cold War. } \\
\text { Links between International Insertion and Development. }\end{array}$ & $\begin{array}{l}\text { Links among International Orders, Development and Conflict. } \\
\text { Focused on Peripheral Regional relationship with International Order } \\
\text { crises and transitions. Formal and Informal Configurations of Power. } \\
\text { New global issues such as Migrations, Environment, Organised } \\
\text { Crime, Pandemics. }\end{array}$ \\
\hline $\begin{array}{l}\text { Epistemic ne- } \\
\text { tworks }\end{array}$ & $\begin{array}{l}\text { Regional foci tied to regional developments in Social } \\
\text { Sciences (Sociology, History, Political Sciences, and } \\
\text { Law). }\end{array}$ & $\begin{array}{l}\text { Regional foci linking mainly Regional and Western networks. } \\
\text { Growing in either dialogue or subordination to Western epistemic } \\
\text { communities' approval. }\end{array}$ \\
\hline Aims & $\begin{array}{l}\text { To comprehend the peripheral political economy of } \\
\text { international insertions and development during the } \\
\text { rise and consolidation of the International Liberal Order. } \\
\text { Inequality and economic backwardness. }\end{array}$ & $\begin{array}{l}\text { To comprehend the peripheral and regional political economy of } \\
\text { development and conflict within a changing global order. }\end{array}$ \\
\hline Ontological axes & $\begin{array}{l}\text { International-Domestic., } \\
\text { State-Market. } \\
\text { International Insertion-Economic Development. } \\
\text { Power-Underdevelopment. }\end{array}$ & $\begin{array}{l}\text { Complex Ontologies subordinated to Space-Time and research focus. } \\
\text { Development-Conflict. } \\
\text { Regional-Global. Formal-Informal Development. } \\
\text { Identity-Development-Crises. }\end{array}$ \\
\hline Epistemology & $\begin{array}{l}\text { Developmentalism. } \\
\text { Dependency Theory. } \\
\text { Political Studies. Macro theoretical perspectives. }\end{array}$ & $\begin{array}{l}\text { Past IPE traditions. } \\
\text { History, Geography, Technology, Security Studies. } \\
\text { Theories derivate and used for research. } \\
\text { Hybridization and Contestation. }\end{array}$ \\
\hline Methodology & From Critical Perspectives to Traditional ones. & $\begin{array}{l}\text { Range and mixing from Positivist to Reflectivist, Post Structuralist } \\
\text { and Critical Security approaches. }\end{array}$ \\
\hline $\begin{array}{l}\text { Teaching and } \\
\text { Learning }\end{array}$ & Focus on Schools. & Research oriented and Regionally differentiated \\
\hline
\end{tabular}

Source: designed by the authors

Facing the impossibility of adopting one single definition of IPE at a global level, it is necessary to make academic sense of the field at a regional level today. In this sense, Latin American GPE can be regarded as an umbrella concept that covers a wide range of different orientations and innovations that are anchored around a variety of ontological and epistemological orientations, manifested in its teaching and research. Despite the fact that their different approaches share something in common, a main quest is to comprehend how the struggle for power and wealth bring about development and conflict (beyond any definition adopted for them), in a field of intersections between international-domestic, state-market, regional-global, and formal-informal realities of development (COHEN, 2019; HELLEINER; ROSALES, 2017; RAVENHILL, 2017). On this basis, it is possible to group them as ideal types, according to the orientations concerning development and conflict in the world order, perspectives, ontologies, and methodologies to facilitate the analysis. This makes it possible to cluster them in a range of typologies, for instance, from the highly empirical positivist to the most interpretative/reflectivist in one axis, and from their ontologies, epistemologies, methodologies, and types of evidence on the other axis. That is a synthesis evident taking into consideration the different debates and contributions in terms of methodological issues. At the same time, this makes it possible to delineate a basic 
map of where IPE and GPE can be found (CRESWELL, 2014; JACKSON, 2011; LAKE, 2013; SAUTÚ et al., 2005) in the context of present debates.

The diagram below is a simple pedagogical resource, which gives students at the very beginning of their formation the different methodological coordinates that cur across the field. It does not pretend to represent any philosophical discussion, on the contrary, just a sociological portrayal of methodological coordinates, so it does not have analytical purposes but logical alignments for basic teaching. The illustration therefore does not have investigative ends but provides a simple way to grasp different methodological strategies and theoretical positions from objectivist and reflectivist ontologies and epistemologies, from general logical avenues from mayor theoretical perspectives and the different components of research. In summary, it illustrates the most commonly used approaches to GPE in their closer or distant relations with the most known ideal-type research designs on the basis of contributions from different scholars (CRESWELL, 2014; HAY, 2002; JACKSON, 2011; LAKE, 2013). The vertical dimensions range from the role of theories in GPE at the top, location of research approaches, the methodological lines to the types of evidence construction that define them. These bring together the ontological, epistemological, and methodological levels of any investigation (HAY, 2002). From the horizontal axis, the diagram ranges from the more empirical positivist designs to more interpretative views (CRESWELL, 2014; JACKSON, 2011). For instance, the methodological possibilities of research design, combining the two extremes of the horizontal axis, are fewer than seeking to merge between closer strands of thoughts, while all research must be logically gathered from all levels.

Figure 1 - Research designs: theoretical and methodological approaches in GPE

\section{Roles of theories in GPE}

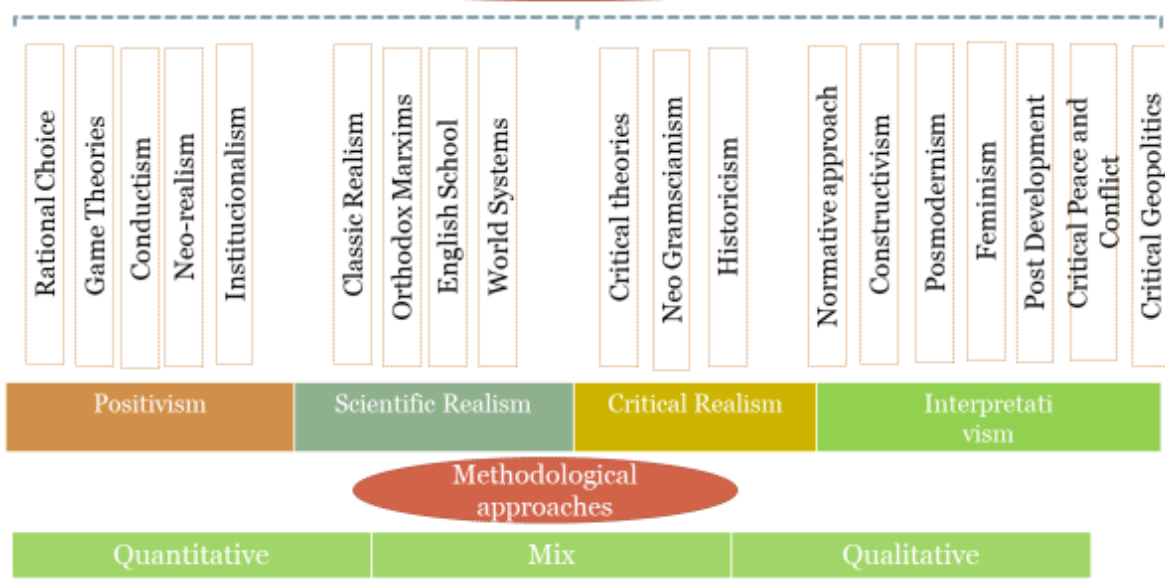

Source: designed by the authors

The advantage of this visualisation of the theories in GPE is that provides us with a brief representation of where theories are situated, and the scope of IPE and GPE in methodological terms, or in other words, concerning the role of theory in research (BURGESS, 1982). In this context, 
English-speaking mainstream IPE, covers widely the OEP and generally located on the objectivist ontological left side as positivist perspectives (COHEN, 2019). These perspectives can be centrally situated on the positivist, quantitative and behaviourist axis, while GPE be lying on the critical, interpretative, and qualitative axis within its diverse range of perspectives (COHEN, 2019; LAKE, 2009; 2013; MALINIAK, 2009; TIERNEY, 2009). The graphic exemplification permits us to identify which one of the different perspectives, ontologies, and epistemologies work more appropriately for the research of different themes.

The point here, however, is to avoid universalism and ahistoricism and facilitate multidisciplinariety and plurality. Hence, LAGPE does not represent an epistemological homogeneous community, under the traditional definition, but a set of different academic networks or niches where teaching and research seek to explain how the reality and conflict come about given the different roles of power in development at the global, regional and national level.

Rather than separate, all levels can be seen as interrelated but within different levels and under specific logical links. Therefore, it is possible to identify global dialogues that include various perspectives at various levels. These global dialogues are interrelations of knowledge (TROWNSELL et al., 2019), which go beyond the inherited foci of Developmentalism and Dependency Theory, open regionalism, Formal and Informal Development and Conflict, Economic and Politics, Global Insertions and Strategic Studies. Thus, LAGPE can be legitimately understood as the continuity of work around decades of contributions of the Latin American schools and scholars concerning development, conflict and their relations with certain international insertions within different world orders, but in dialogue with different global perspectives (DECIANCIO, 2018; TUSSIE, 2020). The key to grasp that is to auscultate the development of the field in the region (DECIANCIO, 2018; TUSSIE, 2018; 2020).

For some scholars, LAGPE is a global post-structural, post-development, or post extractivist approach based on ontological fusions between cultural studies, sociology, and heterodox economics (ACOSTA, 2011; ACOSTA; GUDYNAS, 2018). Unsurprisingly, each academic orientation tends to sustain that they are right and the others wrong, something perhaps more common with older scholars than younger ones. Something which is certainly the result of a lack of dialogue between academic groups, and above all, the result of teaching of young scholars (SALGADO; VIVARES, 2019.

Indeed, given its diversity, no faction or niche can claim a unique and universal ontology, epistemology, or research agenda for LAGPE. However, beyond these reasonable institutional limitations, the segmented field is promoting the generation of research-driven advances and innovations beyond English-speaking mainstream and past regional traditions (TUSSIE, 2018). Unlike the golden age in the 50s and 60s of LAIPE, defined by meta-theories, the remerging LAGPE is, in many cases, a derivation of core research concerns from the past but having been expanded to different development and conflict issues, according to present time, in terms of new lines of research and methodological orientations (TUSSIE, 2018). 
All of that evidences a revival of the field, but there is also a significant issue limiting the area at the postgraduate level, which is the poor appraisement of methodology in teaching and training (both drivers of academic development) (SALGADO; VIVARES, 2019. On the other hand, concerning teaching, regional scholars tend to claim to belong to or follow one IPE theoretical orientation. However, when it comes to research and publishing, they generally define themselves as pluralists and even eclectic and pragmatic. As in the North, teaching in Latin America encourages divides in many cases, but the orientation of syllabi-weak in teaching and training in methodologies - is becoming slowly more pluralist(SALGADO; VIVARES, 2019. For example, a significant number of scholars present themselves as critical and interested in this type of theoretical approach but opt for positivist methodologies and hypothesis testing at the time of both producing research and training new scholars. One professor states: "Postgraduate students, as future scholars, must learn to be critical researchers that produce new ideas finding the right hypothesis to test" (Interview anonym).

Beyond these weaknesses in teaching, there are crucial elements that define the identity of LAIPE/GPE, which must be central components of teaching. The relationship between economics and politics is part of this, but just the beginning of a more complex problem for teaching and research. The central issue with LAIPE/GPE is that they are based on complex and dynamics ontologies that cross different traditional disciplines that explain domestic and international economics, and politics. Regardless of the relevance of economics from the golden age to the present LAGPE, politics remains the base of IPE, but with its variety of ontological elements in the regional case. According to Diana Tussie (2018), the central difference between international and regional IPEs is that the regional contributions lie in the strength and historical succession of their ontologies. Thus, the common point between LAIPE and LAGPE is that their explanations of international-domestic linkages are based on the regional global insertions, development and regional types of conflicts rather than wars, institutions or casino capitalisms, as is the case of mainstream IPEs (KRASNER, 1994; STRANGE, 1994; TUSSIE, 2018). For instance, to explain regional development, Developmentalism and Dependency Theory took as a starting point the ontology of domestic-international interactions and dynamics with the liberal world order during the Cold War. In doing so, the dialogue of LA and mainstream IPE was low, while today, the interrelations of knowledge between both are significant (DECIANCIO, 2018; JIMENEZ-PEÑA et al., 2018). The contributions of traditional LAIPE were rooted in the political-economic history of international insertions according to development models and conflicts in the region (TUSSIE, 2018). In doing so, it thereby dissolved the separation between high formal politics of diplomacy and foreign affairs versus low politics in the hands of technicians (the craft of economic relations) (TUSSIE, 2018, p. 5). After an extensive analysis of the field in the region, Tussie (2018) concludes that LAGPE is being revitalised today via debate and research on global insertions, regionalism, international trade institutions, shadow economies, security and new global-regional development issues (TUSSIE, 2018, p. 10). 
New teaching and research themes that characterised the LAGPE

To identify what is new in the LAGPE or what is defining its shift and new orientations in teaching and research we depart from the mayo ontological orientations that roughly compose them, although with no lineal limits. Taking the notion of ontology as a base for diverse regional-global dialogue (BLAIKIE, 2007; HAY, 2002), we can analytically identify three significant spaces, niches or orientations of conversations between the region and the global shaping the LAGPE. The first is the Institutionalist Market-led, the Neodevelopmentalist/multilateral and Post-development and Post-structuralist (SALGADO; VIVARES, 2019. They differentiate themselves from the historical traditions of Developmentalism and Dependency Theory, although some include their categories in the teaching as roots of LAGPE. In other words, these current orientations are not re-editions or re-inventions of meta-theories based on the historical achievements generated during the time of the Cold War. The incipient and emerging LAGPE is defined by new academic inquiries, adaptations, and conversations with the world order about development and conflict in the last two decades (PEIXOTO, 2017). That is not a discipline, in terms of macro meta-theories with their methodologies and research agendas, but networks or groups, sometimes marked by different national orientations, as in Brazil. Others, instead, are more institutionalised, with their functioning bounded to national hierarchies and strongly oriented to formal IPEs, for example in Colombia and Chile. Finally, others represent critical alternative GPEs, such as Poststructuralist, De-colonial, Feminist, among others, with significant contributions but with poor or no dialogue with formal and mainstream IPEs as a field of study of IR (SALGADO; VIVARES, 2019.

These three distinct spaces in LAGPE make up regional GPE today, and what they share is the researching and understanding power, development and conflict, region-world order interactions and dynamics, from different perspectives, in a time when formal IPEs appear limited to giving responses. It is within these three different regional academic orientations that we can trace what regional scholars are doing (researching, teaching, and publishing) in the LAGPE (DECIANCIO, 2018; MADEIRAS et al., 2016; TUSSIE, 2018).

The three LAGPE, mentioned above, however, do not share the same perspectives about the world. Instead, in some cases, they display different ontological and methodological dialogues with North American IPE, other GPE, and Eurocentric GPE (JIMÉNEZ-PEÑA et al., 2018; TUSSIE, 2018). Such conversations vary according to the political-economic views of development and conflict underlying each GPE. Hence, some of them focus their research on different issues both in and outside of the mainstream, such as development, global insertions, regional multilateralism, development financing, formal/informal political economy, social issues and policies, gender and identities, conflict, security, defense, technologies and their governance, cities and environment.

For instance, Institutionalist Market-led perspectives bring together different meta-theoretical views such as liberal-rational institutio- 
nalism, neoclassical economics and is associated with the longest liberal and conservative tradition in Latin American academy. These perspectives are theoretically bound to North American Political Science and Neoliberal Political Economy, known today as Open Economy Policy. With strong roots in behaviourism, positivism, and empiricism (KING et al., 1994), authors writing from these perspectives primarily focus on formal domestic-regional or global links concerning their institutional configurations, economic openness, trade integration, and anti-populism (DORNBUSCH; EDWARDS, 1992;; RABELLO DE CASTRO et al., 1991). Intuitionalist Market-led epistemology starts from the premise that the economic history of Anglo-Saxon markets from Europe to the United States is the central paradigm of Western capitalism: the only formula for the region (NORTH, 2005). Market outcomes, trade agreements, national convergence, and national and supranational institutionality are the essential variables to consider (LAKE, 2009;). Proponents assume that the North American economy and the European Union (EU) are successful historical, universal experiences of development and integration, and, therefore, that they form the mandatory criteria to evaluate Latin American (LA) political economy (STURZENEGGER, 1992. In other words, the central critiques can be summarised in what Acharya (2011, p. 631) terms the North American, Western economic, and Eurocentric regionalism with their false universalism.

The second set of perspectives focus on regional transformations and multilateral reorientations of LA, following the temporal decline of the Washington-sponsored regional multilateralism and its institutions, at the peak of the pink tide, and in many cases close related to constructist approaches. ${ }^{5}$ The ontology of these viewpoints rest on the rise of new post-hegemonic and post-neoliberal realities of development as lines of conversation between the regional and the global. Its view of IPE is multilateralist in politics and neostructuralist in economics (LEIVA, 2008). Through research, authors have focused on unpacking the agency of pluralities, complexities, and new regional issues of development (RIGGIROZZI; TUSSIE 2012; SANAHUJA, 2010). Although with minimal consideration of economic integration, regionalism has been central for it, marked by hyper-presidentialism and the inclusion of social and security issues in the agenda of development (BONILLA; LONG, 2010; QUILICONI; SALGADO, 2018). Research thus concentrates on the rise and decline of different regional schemes, marrying epistemologically neodevelopmentalist economics with political multilateralism. For proponent, the new LAGPE relies on the hegemonic differentiation offered by the competition between North America, EU, and South East Asia (ESTAY; SANCHEZ, 2005; SANAHUJA, 2010; RIGGIROZZI; TUSSIE 2012). Today, after the shift from progressivism to centre-right regionalism, a central critique is the absence of a sound reflection on an autonomous regionalism when the region shares the hemisphere with the global hegemon (NOLTE; MIJARES, 2018).

Third and finally, exponents of the commodities consensus, post-extractivist, or postdevelopmental perspectives who argue that, the new world system of development forces the region into new paths of
5. The term 'pink tide' comes from political science and it describes a shift in the orientation of Latin American governments from neoliberalism to progressive, left-wing, and populist policies beginning with the administration of Hugo Chavez in Venezuela, in the late 1990s. 
6. For instance,; BRICEÑO; MORALES, 2017; DECIANCIO, 2018; NEMIÑA, 2011; PONTÓN, 2018; PONTÓN GUAYASAMIN, 2018; PRIETO, 2019; QUILICONI et al., 2015; RETTBERG et al., 2018; RIGGIROZZI; TUSSIE, 2012;; PEIXOTO, 2017.

7. International Organization, New Political Economy, Review of International Political Economy, and Third World Quarterly.

8. Latin American Perspectives, Journal of Latin American Studies, Latin America Politics and Society, and Latin America Research Review.

9. Within Northern regional values, Mexico is not over $2 \%$. 'underdevelopment,' especially with the rise and impact of South East Asia (PETRAS; VELTMEYER, 2012). The scenario of development is characterised by a return to economic reprimarization, complex rentier states, and new asymmetries that have exacerbated inequalities, destruction of the environment and shifted the region to conservative politics (ACOSTA, 2011; DELGADO, 2016; CAJAS-GUIJARRO, 2018; SVAMPA, 2013; ROJAS, 2013). For them, the system has been able to finance poverty reduction programmes, rising wages, expand social expenditure, but co-opting at the same time, trade unions, local communities, and social movements without creating a real transformation of the neoliberal order (GUDYNAS, 2018).

In terms of publishing, the presence of these three niches is noticeably weak, not only because of language barriers but also because of the concentration of the top journals in the North American and European production concerning Latin America. LAGPE scholars have poor access-more so in terms of gender-to the core group of international journals, in both IR and LAIPE. Although recently there has been fast-growth and signals of strengthening, ${ }^{6}$ apart from a handful of LA academics working, the publication presence has been scarce in the last two decades. Numbers do not speak for themselves but can show who accesses them and the themes prioritised in the journals for academic discussion. The explorative analysis of the editorial boards in a sample of core IPE journals ${ }^{7}$ and a central Latin American international journal ${ }^{8}$ demonstrate a primary trend showing an approximate of how the IR and IPE of LA is produced and published today. In IPE journals, over $70 \%$ of the editorial board members are male, $30 \%$ are female, $42 \%$ are from North America, including the U.S., Canada and Mexico ${ }^{9}, 29 \%$ are from Britain, $12 \%$ are from Europe, $10 \%$ are from Asia, and only $7 \%$ are from South America. Professionally, $57 \%$ are political scientists, $21 \%$ are economists, $10 \%$ are internationalists, and $6 \%$ are sociologists (SALGADO; VIVARES, 2019. In the case of Latin American international journals, something similar occurs: $64 \%$ are male, $36 \%$ are female in the editorial boards, $30 \%$ come from the U.S., $24 \%$ are from Britain, $12 \%$ are from Europe, and only a small quantity, $7 \%$, are from South America, while the distribution of professions is $40 \%$ political scientists, $21 \%$ historians, $20 \%$ sociologists, $9 \%$ economists, and $6 \%$ philosophers (SALGADO; VIVARES, 2019). Males, U.S.-British academics and universities, English speakers, and political scientists seem to be the structural pattern in the composition of the filters of IPE and orients both about how mainstream IPE is produced and how LA is understood.

Beyond the reduced attention of the international journals to new contributions of LAGPE the feature today is a growing, heterogeneous, pluralist, and transdisciplinary field of research bound to the different conversations, and inquiries concerning development and conflict, within the hemispheric and global order. It differs from golden LAIPE because it represents a sprouting academic trend with multiple responses and research on the current changing historical order and regional reconfigurations of development. In contrast, the past 
LAIPE was defined by the Developmentalist and Dependency Theory during the Cold War, Keynesian economics, and the Monroe doctrine. LAGPE today is entwined with different types of complex and regional issues, which do not gravitate in the same way as mainstream IPEs. Rather, past and present LAIPE tend to produce situated knowledge, adopting key elements but also going beyond the limits of the field's mainstream approaches. LAGPE can therefore be considered interdisciplinary or transdisciplinary depending on the orientations.

Thus, there are various new emerging lines that differentiate LAIPE from LAGPE. One of these lines is how scholars adopt and use their research with similar or different ontological and epistemological foundations defines the precise contours and limitations of the new LAGPE. Research in the LAGPE includes past traditions, new concerns and ideas, and different conversations which brought about new research orientations shaping the international and regional field while taking it away from conventional theories. Themes that are the central focus of this tendency include regional reconfigurations, global insertions, formal/informal development, inequality, social emergencies, transnational organised crime, security and defence, development finance, technologies, and change, extractivism and natural resources. Undeniably, the main focus the LAGPE has been the theme of regionalism, whereby research has sought to conjugate mainstream and alternative theories and concepts with new problematics, according to the different perspectives adopted. The majority of research and debate about regionalism has been carried from Neoliberal - Conservative, and Neodevelopmentalist -Multilateralist perspectives. The focus in this case is on the official craft of either left or right governments, as top-down, institutional, and formal economic processes of integration (MALAMUD; GARDINI, 2012; NOLTE; MIJARES, 2018; QUILICONI; SALGADO, 2018; STURZENEGGER, 1992). However, there are other academic contributions to regionalisms, in this case focusing on non- state actors, informal regionalisms, driven by the political left or the political right and the importance of their regional reconfiguration. According to these perspectives, the pink tide and the Alliance for the Progress are part of the same regional reconfiguration of Latin America, something that cannot be grasped within the analytical frame of the world order, American hemisphere, the rise of China and U.S. hegemony (NOLTE; MIJARES, 2018;; VADELL, 2018, VIVARES, 2017

Moreover, the hemispheric and regional reconfiguration prompted new research issues that have reshaped the field from LAIPE to a sort of a new LAGPE. In this context, scholars began to discover and develop a vital issue, something that would bridge the past and present academic IPE orientations, that is regionalism (TUSSIE, 2018). Therefore, despite the wave of hemispheric, dictatorial, neoliberal and progressist perspectives, those transformations did not erase the historical political instability, inequality, and commodity-oriented regional insertions of the past. According to new studies, research also continued unaltered and has even increased despite both the neoliberal and neodevelopmentalist attempts 
to change it during the two decades following the Cold War (ASTORGA, 2015; PONCE et al., 2018).

Finally, between the end of the 90 s and the beginning of the new century, LAGPE has gradually taken form, addressing specific issues about development such as inequality, global insertions, and regional political orientations. Examples of this are the studies about formal regional reconfiguration, which can be traced to trade and finance (MORALES, 2017; PÉREZ-OVIEDO et al., 2018; VADELL, 2018). However, if we compare this with past LA IPE, the field also began to open another set of research issues, such as what some scholars have termed informal and malignant regional configurations across national boundaries (PONTÓN; GUAYASAMÍN, 2018) (i.e. drug trafficking, organised crime and informal economies, among others). That brought different ontologies and epistemologies together, demanding different research tools and approaches to grasp the so-called informal, shadow, covert configurations or new identities in IPE. In doing so, the nature of the inter- or transdisciplinarity field has begun to take shape (MACDONALD, 2017; RIVERA; PÓNTON, 2016; TAYLOR, 2005).

Another key theme of research focus is the transformation of the region. Now we have a different Latin America. The central regional transformation was driven by the geopolitical economic and hemispheric reorientation of Mexico, its detachment from Latin America, and its inclusion within the North American political economy (BONILLA; LONG, 2010;). A historical change that recently became crystallised in the signing of CUSMA (Canada-United States-Mexico Agreement), the new North American trade agreement. Briefly, the cycle of regional differentiation ended with the diversification of the South's regional insertion in the U.S., China, and Europe triggering the revitalisation of the South American Political Economy research in all its perspectives (ACOSTA, 2011; ESTAY, 2018; RIGGIROZZI; TUSSIE, 2012; SANAHUJA, 2010).

A third theme of research interest is the informal political economy, focused on the informal, shadow economies and covert world. These distinct areas of investigation are connected to the insertion of the region globally. As a matter of fact, given the academic anchor in Western and Anglo-Saxon countries, formal mainstream IPEs tend to limit the focus on these realities that distinguish the South. The region is not only the most unequal in the world, but it is also a region with the most extensive informal and shadow economies (ABDIH; MEDINA, 2013; FELD; LARSEN, 2009; MEDINA; SCHNEIDER, 2018). 


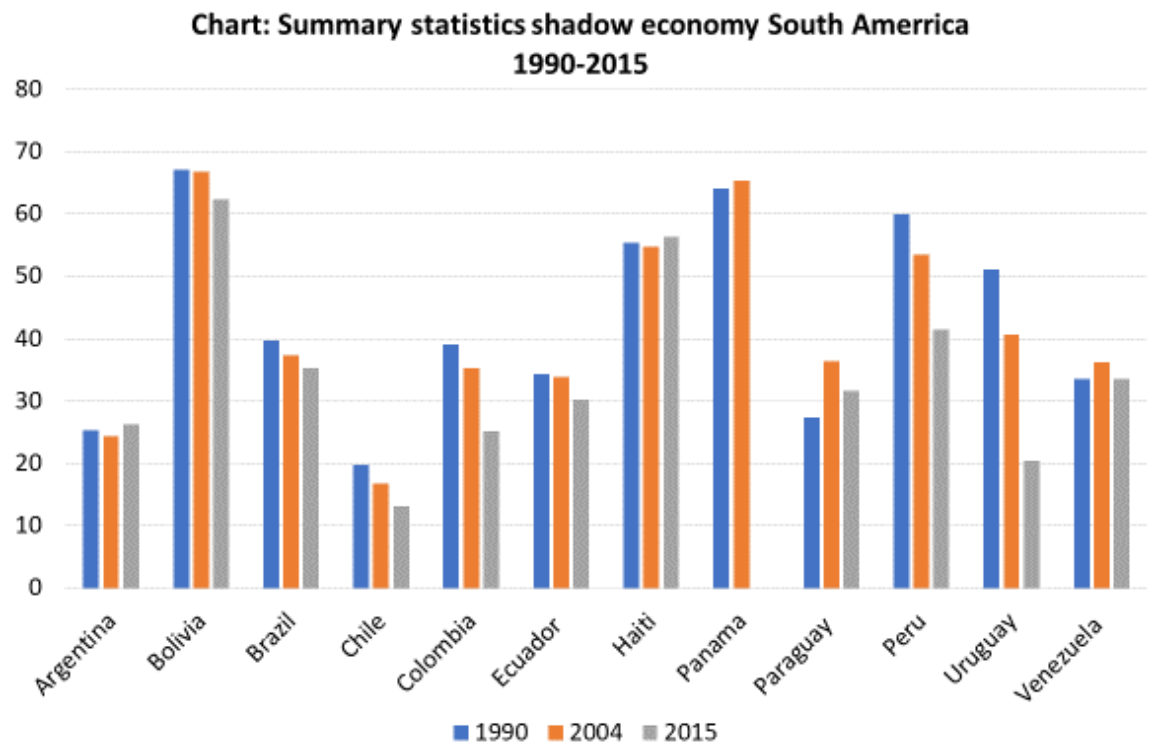

Source: Leandro Medina and Friedrich Schneider, 2018.

Informal economies (and informal regional world), with all their diverse dimensions and issues, deserve their own agenda in the field since they are a distinctive and significant feature of the region. This is something that has not previously been in the content or in the ontologies of mainstream IPEs. New research on these areas identifies central dimensions interrelated with the political economy: organised crime, drug trafficking, money laundering, solidarity between urban and rural economies, gun trafficking, illegal mining, informal work and informal migration and frontiers without states (BERGMAN, 2018; PONTÓN; GUAYASAMÍN, 2018; RIVERA; PONTÓN, 2016).

Other characteristics of LAGPE is the focus of research on a new geography of businesses. This kind of research clearly goes beyond mainstream IPEs and LAIPE. For instance, recent research by Saguier and Ghiotto (2018) explores the regional PE of business and economic governance in their interactions with development and environment, highlighting its current geographical importance of food production in LA. The focus on these research topics is entwined with new global insertions of the international political economy in the region. Today's research in LAGPE examines also the changes coming from the rise of China and its impact as a new source of development finance upon the region (GALLAGHER, 2016; RODRIGUEZ, 2019; STANLEY; FERNANDEZ, 2018; VADELL, 2018), whereas the old LAIPE centred in historical regional dependence of external development finance, its relationship with global insertions, inequality and the instability of political order (BERTOLA; OCAMPO, 2012; DIAZ ALEJANDRO, 1988; GRIFFITH-JONES, 1984). The focus on China is related to its new role as a new source of finances for the region. Strikingly, according to Myers and Gallagher (2018), even with a drop-in lending in 2017, Chinese state-to-state finance lending to Latin America surpasses that of the World Bank, the Inter-American Development Bank, and the Andean Financial Corporation. 
Besides global insertion, the focus of research on inequality can be considered as a constant of LAIPE that is reflected on LAGPE (TUSSIE, 2020). Inequality has historically been one of the common ontological sides of the different perspectives of LAIPE and continues present in LAGPE (TUSSIE, 2018). Past and present research shows a strong historical correlation between changes and orientations of development finance and diverse orientations of regional development (ASTORGA, 2015; FRANKEMA, 2010; GASPARINI; LUSTIG, 2011; THORP, 2012). The contention from LAGPE is that if the mantra of IPE is the study of how power shapes the distribution of wealth at global, regional, and national levels, inequality should be at the centre of the research agenda, as it is defined by power. Categorically, this disappears in mainstream IPE, since it is concerned, in its dominant branches, mostly with the study of agency and institutions, markets and politics within the liberal order.

Migration has become to be another important theme of study of LAGPE. Neither mainstream or old LAIPE have considered migration to be a significant issue, except in the sense of public policies or international regimes, usually studied from the perspective of the agency. Immigration, however, has now become an important research topic within the LAGPE. It centres the attention on the comprehension of its formal and informal dynamics and on the difference between the concept of migration and conflicts (MATTIUZZI DE SOUZA 2020; MIERES, 2020;). For decades, in Latin America, this has been a social factor accompanying inequality, political instability, and international insertions, and because of this it is a critical regional dialogue among GPE and sociology-a necessary and significant source of research- (CANALES, 2018), which recently is a relevant topic of research within the field.

A final characteristic of LAGPE is its focus on the role of cities in the international political economy. Although the concept has been present in social sciences for ages and helped to explain the agency and development of governance, the GPE of cities is a growing line of research in the region, acting as a central anchor and a container for time, political-economic geography, and social dynamics (MUGGAH, 2015; SASSEN, 2005). Perhaps, given its primary focus on institutions and agencies, and formal politics mainstream, IPE has not, however, sufficiently opened its conceptual frameworks to different realities and geographies. Cities are urban geographical anchors, and metropolitan centres where inequalities, shadow economies, violence, gender, migration, and environmental issues are interrelated with the formal political economies of development and conflict (FUENTES; DURAN, 2018). Contributions in these areas are growing in the region and are growing research areas in South America and IPE in some places in the Global North (MACDONALD, 2017; MUGGAH, 2015).

Conclusions

In conclusion it is possible to say that globally the field is limited when it comes to providing explanations regarding the decline of the liberal order, unprecedented violence, more so at the social and environmental level. The politics of Donald Trump, Nigel Farage, Victor Orban, 
Matteo Salvini, Giuseppe Conte, and Jair Bolsonaro and the following regional shift in South America, viewed from the top, represent the misfortunes of the liberal cosmopolitan order in decline that mainstream IPE can barely explain. However, seen from below and diachronically, they look more like a Polanyian circle where neoclassical economies and unleashed market kill liberal orders and elites via inequality, which in turn, calls Caesarean leaderships to avenge fragmented and denigrated societies to establish new orders (POLANYI, 2001). In stable times, fixed knowledge explains realities. In times of change, the research speaks, and that is the trial of GPE today.

This paper's aim was to get a picture of the transition of mainstream LAIPE to what we called LAGPE. We identified some contours or themes of teaching and research that show a shift from the old LAIPE towards an increasing and flourishing LAGPE, as a form of renewal of the field.

LAGPE offers specific responses, adaptations, and interrelations of knowledge in response to the contemporary challenges of regional and global development and conflict. LAGPE focuses on various and different new areas such as formal and informal powers of the domestic and international field, on subjectivities and material conditions, while also maintained in the teaching, learning and research of the old LA IPE. It takes into consideration the ontological setting that is defined by different historical and geographical characteristics. Hence, we have witnessed a revitalisation of the field marked by a wide range of contributions and a pluralist and interdisciplinary academic perspective.

Another feature is that Latin American GPE is not defined by a unique theoretical or methodological approach, by one school, a particular ontological or epistemological position., or by a homogeneous regional view. Teaching, research, and publishing in Latin America are remain on a small scale compared to the Global North. However, it has taken the directions of a LAGPE in line with a GPE. Therefore, LAGPE can be understood as a set of historical narratives and networks of different generations, like diverse historical layers overlapping and connecting with one another, based on a range of different experiences, academic challenges, and orientations.

The paper demonstrates in agreement with Lake (2016) that for the last 40 years IR/IE and IPE have been dominantly derivate of the North American political sciences, English-speaking, male, white, and centrally located in western academic centres. Therefore, through the construction of the reality of IR, many geographies and epistemologies were left out and overlooked in the determining of intellectual prizes within the field of economics, where these should be given and where they should be awarded. The LAGPE as a category, academically and geographically, can be examined in the light of this, and constructed in relation to the past contributions of Developmentalism, Dependency Theory and Regional Multilateralism of the 90 s.

Experience in the field shows that such issues can be addressed via the production of possible and logical methodological unions between different assumptions about the role of theory in research. It also 
highlights methodological combinations, for example between the extreme empiricist-positivist to the critical, from agency focused perspectives to more structural orientations. In this context, the field can best be understood as a multilevel map of different ontologies, epistemologies, methodologies, and types of evidence produced by cutting across the wide range of theories and the different roles they can assume in the research. Pluralism and interdisciplinarity have long been asserted by emphasising different philosophical positions and claim about or against mainstream or Western International Relations/Studies (ACHARYA, 2011; JACKSON, 2011; TICKNER, 2003).

To conclude, the problem for the field of LAGPE continues to be twofold. First, is the methodological task of how to assemble research puzzles in GPE that can bridge, different levels: domestic-international and agency-structure. The second concerns the demand for the conception of plurality and interdisciplinarity as a condition for the existence of a GPE, and this research found that this implies an understanding of the field more closely related to a space of research than a monolithic discipline. Accordingly, any attempt to expand the boundaries of mainstream IPE must be a research endeavour oriented to complement rather than to replace formal IPEs, but the task does not end there since this must be the starting point. Perhaps the primary outcome is more a question rather than a premise: To what extent should a field of inquiry, such as GPE, be open to combinations of the formal, informal and global insertion of political economies? This represents a different task, one that goes beyond essentialism, ahistoricism, and which crosses the divides between international and regional IPEs, and it is also a methodological invitation to more global and associated research.

A final remark is that LAGPE accounts for the stark absences in its teaching and research concerning crucial issues of development and conflict: gender, aboriginal rights, defence and security, business, change in value, cyber change and governance, and the environment are only some of them. Gender is a paradox and the foremost weakness in LAGPE today. Paradoxically, the presence of feminist GPE production is practically non-existent in the region, but almost half of the postgraduate programmes are driven by leading female scholars in the field. Hence, the field faces the challenge of remaining open to dialogue with gender studies and feminist sociologists in the region who have been historically the source of that line of research.

References

ABDIH, Y.; MEDINA, L. Measuring the Informal Economy in the Caucasus, and Central Asia. International Monetary Fund, WP/13/137, 2013.

ACHARYA, A. Dialogue and discovery: in search of international relations theories beyond the west. Millennium, v. 39, n. 3, p. 619-37, 2011.

ACOSTA, A.; GUDYNAS, E. Lecciones del caso Bolsonaro: Lecturas para una nueva izquierda. 2018. Disponible en: https//www.planv.com.ec

ACOSTA, A. Extractivismo y neo extractivismo: dos caras de la misma maldición. Varios autores. Mas allá del desarrollo, Grupo Permanente de Trabajo sobre alternativas de Desarrollo, Universidad Politécnica Salesiana/Fundación Rosa Luxemburgo, Quito, Ecuador, 2011. 
AGNEW, J. The Territorial Trap: The Geographical Assumptions of International Relations Theory. Review of International Political Economy, v. 1, n. 1, p. 53 - 80, 1994.

AMIN, S. Eurocentrism. New York: Monthly Review Press, 1988.

ASHWORTH, L. A revisionist history of International Relations. International Relations, v. 16, n. 1, p. 33-51, 2002.

ASTORGA, P. Functional Inequality in Latin America: News from the Twentieth Century. Discussion Papers in Economic and Social History, n. 135, 2015.

BERGMAN, M. Illegal Drugs, Drug Trafficking and Violence in Latin America. New York: Springer, 2018.

BERTOLA, L.; OCAMPO, J.A. El desarrollo económico de América Latina desde la independencia. Oxford: Oxford University, 2012.

BLYTH, M. Routledge Handbook of International Political Economy. New York: Routledge, 2009.

BONILLA, A.; LONG, G. Un nuevo regionalismo sudamericano. Íconos: revista de Ciencias Sociales, n. 38, p. 23-28, 2010.

BLAIKIE, N. Approaches to Social Enquiry. Cambridge: Polite. 2007.

BRICEÑO, J.; MORALES, I. (eds.) Regionalism in the Americas: Toward a Pacific-Atlantic Divide? New York: Palgrave, 2017.

BURGESS, R. The Role of Theory in Field Research. In: BURGEES, R. (ed.) Field Research: A Sourcebook and Field Manual. London: Routledge, 1982. p. 209-212.

CAFRUNY, A. Introduction. In: CAFRUNY, A.; TALANI, L.; POZO, G. (eds.). The Palgrave Handbook of Critical International Political Economy. London: Palgrave Macmillan: 2016. p. 1-8.

CAJA-GUIJARRO, J. Los capos del comercio: concentración, poder y acuerdos comerciales en el Ecuador. Quito: Ecuador decide sin TLC, 2018.

CANALES, A. Global and Regional Political Economy of Migration. In: VIVARES, E.(ed.), Regionalism, Development and the Post-Commodities Boom in South America. New York: Palgrave Macmillan, 2018. p. 243-270.

CARVALHO, A.; GIL-PEREZ, D. Formação de professores de ciências: tendências e inovações. 10. ed. São Paulo: Cortez, 2011. 127 p. (Questões da nossa época, v. 28) ISBN: 9788524917257.

COHEN, B. Advanced Introduction to International Political Economy. Cheltenham, UK: Edward Elgar, 2014.

COHEN, B. Advanced Introduction to International Political Economy. 2. ed. Cheltenham, UK: Edward Elgar, 2019.

COX, R. The Political Economy of a Plural World. New York: Routledge, 2002.

CRESWELL, J. Research Designs: Qualitative, Quantitative and Mixed Methods Approaches. 4.ed. London: SAGE, 2014.

DECIANCIO, M. La Economía Política Internacional en el Campo de las Relaciones Internacionales argentinas. Desafios, v. 30, n. 2, p. 15-42, 2018.

DELGADO, J. Sociedades post neoliberales en América Latina y persistencia del extractivismo. Economía Informa, v. 396, n. 1, p. 84-95, 2016.

DIAZ ALEJANDRO, C. Open Economy, Closed Polity? In: VELASCO, A. Trade, Development and the World Economy. New York: Basil Blackwell, 1988. p. 283-309.

DORNBUSCH, R.; EDWARDS, $S$ (Ed.). The Macroeconomics of Populism in Latin America. Chicago: University of Chicago Press, 1992.

ELIAS, J. The gendered political economy of control and resistance on the shop floor of the multinational firm: A case study from Malaysia. New Political Economy, v. 10, n. 2, p. 203-222, 2013.

ESTAY, J. Past and Present of Latin American Regionalisms, in the Face of Economic Reprimarization. In: VIVARES, E.(ed.). Regionalism, Development and the Post-Commodities Boom in South America. New York: Palgrave Macmillan, 2018. p. 47-76.

ESTAY, J.; SÁNCHEZ, G. (Coord.). El ALCA y sus peligros para América Latina. Buenos Aires: CLACSO, 2005.

FELD, L.; LARSEN, C. Undeclared Work in Germany 2001-2007 - Impact of Deterrence, Tax Policy, and Social Norms: An Analysis Based on Survey Data. Berlin: Springer, 2009. 
FRANKEMA, E. Reconstructing labor income shares in Argentina, Brazil and Mexico 18702000. Journal of Iberian and Latin American Economic History, v. 28, n. 2, p. 343-374, 2010.

FRIEDEN, J.; LAKE, D. International Political Economy: Perspectives on Global Power and Wealth. Boston: Bedford/St. Martin’s, 1999.

FUENTES, L.; DURÁN, G. Cities in the South American Development: Bogota, Lima, Quito, and Santiago in Regional Frame. In: VIVARES, E.(ed.). Regionalism, Development and the Post-Commodities Boom in South America. New York: Palgrave Macmillan, 2018. p. 217-242.

GALLAGHER, K. The China Triangle: Latin America's China Boom and the Fate of the Washington Consensus. New York: Oxford University Press, 2016.

GASPARINI, L.; LUSTIG, N. The Rise and Fall of Income Inequality in Latin America, 27. Buenos Aires: Universidad de La Plata, ECINEQ WP/CEDLAS, 2011.

GILPIN, R. The Political Economy of International Relations. New York: Princeton University Press, 1987.

GRIFFITH-JONES, S. International Finance and Latin America. New York: St. Martin Press, 1984.

GROSFOGUEL, R. A Decolonial Approach to Political-Economy: Transmodernity, Border Thinking and Global Coloniality. Kult 6 - Special Issue Epistemologies of Transformation: Roskilde, 2009.

GROSFOGUEL, R. From Postcolonial Studies to Decolonial Studies: Decolonizing Postcolonial Studies: A Preface. Review, v. 29, n. 2, 2006.

GROSFOGUEL, R.; CERVANTES-RODRIGUEZ, A. The Modern/Colonial/Capitalist World System in the Twentieth Century: Global Processes, Antisystemic Movements, and the Geopolitics of Knowledge. United States: Greenwood Press, 2000.

GUDYNAS, E. Diez tesis urgentes sobre el nuevo extractivismo. Contextos y demandas bajo el progresismo actual. In: CENTRO ANDINO DE EDUCACIÓN POPULAR (ed.) Extractivismo, política y sociedad. Quito: CAAP y CLAES, 2012. p. 187-225.

HAY, C. Political Analysis: A Critical Introduction. New York: PALGRAVE MACMILLAN, 2002 .

HELLEINER, E. Peripheral Thoughts for International Political Economy: Latin America Ideational Innovation and the Diffusion of the Nineteenth century Free Trade Doctrine. International Studies Quarterly, v. 61, p. 924-934, 2017.

HELLEINER, E. Globalising the classical foundations of IPE thought. Contexto Internacional, v. 37, n. 3, p. 975-1010, 2015.

HELLEINER, E.; ROSALES. Toward Global IPE: The Overlooked Significance of the Haya-Mariategui Debate. International Studies Review, v. 19, p. 667-691, 2017.

HOBDEN, S.; HOBSON, J. (eds.). Historical Sociology of International Relations. New York: Cambridge University Press, 2002.

HOBSON, J. Part 1-revealing the Eurocentric foundations of IPE: a critical historiography of the discipline from the classical to the modern era. Review of International Political Economy, v. 20, n. 25, p. $1024-54,2013$.

INTERVIEW. Marcelo Saguier. Enero 2019. Entrevistado online por Ernesto Vivares.

JACKSON, T. The conduct of inquiry in international relations: Philosophy of science and its implications for the study of world politics. New York: Routledge, 2011.

JIMÉNEZ-PEÑA, G.; LEITERITZ, R.; URREGO-SANDOVAL, C. Dossier, Estado del Arte de la Economia Politica Internacional en Latinoamerica. Revista Desafios, v. 30, n. 2, p. 9-11, 2018.

KEOHANE, R. The old IPE and the new. In: PHILLIPS, Nicola; WEAVER, Catherine (eds.). International Political economy: Debating the Past, Present and Future. London: Routledge, 2011. p. 34-46.

KING, G.; KEOHANE, R.; VERBA, S. Designing Social Enquiry: Scientific Inference in Qualitative Research. New York: Princeton University Press, 1994.

KRASNER, S. International political economy: abiding discord. Review of International Political Economy, v. 1, n. 1, p. 13-19, 1994.

KRUGMAN, P.; OBSTFELD, M. International Economics: Theory and Policy. United States: Pearson International Edition, 2005. 
LAKE, D. Open Economy Politics: A Critical Review. Review of International Organizations, v. 4, n. 3, p. 219-244, 2009.

LAKE, D. White Man's IR: An Intellectual Confession. Perspectives on Politics, v. 14, n. 4, p. 1112-1122, 2016.

LAKE, D. Theory is dead, long live theory: The end of the Great Debates and the Rise eclecticism in International Relations. European Journal of International Relations v. 19, p. 57-587, 2013.

LEITERITZ, R.; RIAÑO, M. Tras el corazón verde: los vaivenes del conflicto en la región esmeraldera de Colombia. In: RETTBERG, A.; LEITERITZ, R.; NASI, C. (comps.). Diferentes recursos, conflictos diferentes: La economía política del conflicto armado y la criminalidad en las regiones de Colombia. Bogotá: Ediciones Uniandes, 2018.

LUXTON, M. The production of life itself: gender, social reproduction and IPE. In: ELIAS, J.; ROBERTS, A. (eds.). Handbook on the International Political Economy of Gender. London: Edward Elgar, 2018. p. 37-49.

MACDONALD, L. The Politics of Violence in Latin America and the Caribbean. New York: Cambridge University Press, 2017.

MADEIRAS, M.; BARNABE, I.; ALBUQUERQUE, R.; LIMA, R. What does the field of International Relations look like in South America? Revista Brasileira de Political Internacional, v. 59, n. 1, 2016.

MADHOK, S.; SHIRIN, R. Agency, Injury, and Transgressive Politics in Neoliberal Times. Signs, v. 37, n. 3, p. 645-669, 2012.

MAHMOOD, S. The Politics of Piety. Princeton: Princeton University Press, Segato, 2005.

MALIK, K. The quest for a moral compass: a global history of ethics. London: Atlantic, 2014.

MALAMUD, A.; GARDINI G. Has Regionalism Peaked? The Latin American Quagmire and Its Lessons. The International Spectator, v. 47, n. 1, p. 116-133, 2012.

MALINIAK, D.; OAKES, A.; PETERSON, S.; TIERNEY, M. International Relations in the US Academy. International Studies Quarterly, v. 55, p. 437-64, 2011.

MALINIAK, D.; TIERNEY, M. The American School of IPE. Review of International Political Economy, v. 16, n. 1, p. 6-33, 2009.

MATTIUZZI DE SOUZA, G. IPE of Borders: between Formal and Informal Regionalisms. In: VIVARES, E. (ed.). Handbook of International Political Economy. New York: Routledge, 2020.

MEDINA, L.; SCHNEIDER, F. Shadows Economies Around the World: What did we learn over the last 20 years? IMF: Working Paper 18/17, 2018. Available at: https://www.imf.org/ en/Publications/WP/Issues/2018/01/25/Shadow-Economies-Around-the-World-What-Did-We-Learn-Over-the-Last-20-Years-45583. Accessed: 21 apr. 2018

MIERES, F. Migration and International Political Economy. In: VIVARES, E. (ed.), Handbook of International Political Economy. New York: Routledge, 2020.

MIGNOLO, W. (2016). Global Coloniality and the World Disorder. Decoloniality After Decolonization and Dewesternization After the Cold War. World Public Forum "Dialogue of Civilizations, 2016. Available at: https://www.academia.edu/21395973/Global_Coloniality_ and_the_World_Disorder_Decoloniality_after_Decolonization_and_Dewesternization_after_the_Cold_War. Accessed: 2 feb. 2018.

MORALES, I. The renewal of U.S. Free Trade" diplomacy in the Americas: From Nafta to a deeper agenda of competitive liberalization for the region. In: BRICENO, Jose; MORALES, Isidro (eds.) Regionalism in the Americas: Toward a Pacific-Atlantic Divide? New York: Palgrave, 2017. p. 32-56.

MUGGAH, R. A Manifesto for the Fragile City. Journal of International Affairs, v. 68, n. 2, p. 19-36, 2015.

MYERS, M.; GALLAGHER, K. Chinese development finance "down but not out" in Latin America. Global Americans, 30 mar. 2018.

NEMIÑA, P. La relación entre el FMI y los Gobiernos tomadores de créditos. Los procesos de negociación con la Argentina durante el estallido y la salida de la crisis de la convertibilidad (1998-2006), 2011. Tesis doctoral, Facultad de Ciencias Sociales.

NOLTE, D. Costs and Benefits of Overlapping regional Organizations in Latin America: The cases of OAS and UNASUR. Latin American Politics and Society, v. 60, n. 1, p. 128-153, 2018.

NOLTE, D.; MIJARES, V. Regionalismo Poshegemónico en crisis. ¿Por qué la Unasur se desintegra? Foreign Affairs Latinoamérica, v. 18, n. 3, p. 105-112, 2018. 
NORTH, D. Institutions, Institutional Change, and Economic Performance. Cambridge: Cambridge University Press, 1990.

NORTH, D. Understanding the Process of Economic Change. New York: Princeton University Press, 2005.

O’BRIEN, R.; WILLIAMS, M. Global Political Economy. New York: Palgrave, 2016.

OATLEY, T. International Political Economy. New York: Routledge, 2013.

PALMA, J. Why Did the Latin American Critical Tradition in the Social Sciences Become Practically Extinct?. In: BLYTH, Mark (ed.). Routledge Handbook of IPE: IPE as a Global Conversation. London: Routledge, 2009. p. 243-265.

PARPART; PARASHAR (eds.). Rethinking Silence, Voice and Agency in Contested Gendered Terrains. London: Routledge, 2018.

PEIXOTO BATISTA, J. La EPI y las Relaciones Internacionales, ¿Dónde está el Derecho?. Relaciones Internacionales, v. 26, n. 52, p. 181-194, 2017

PETRAS, J.; VELTMEYER, H. The Rise and Demise of Extractive Capitalism. The James Petras Website, 04 jul. 2012. Available at: http://petras.lahaine.org/?p=1895. Accessed: 14 mar. 2018

PÉREZ-OVIEDO, W.; CAJA-GUIJARRO, J.; VALLEJO, C. South America: Trade and Integration in the New Global Trade Network. In: VIVARES, E.(ed.). Regionalism, Development and the Post-Commodities Boom in South America. New York: Palgrave Macmillan, 2018. p. 121-146.

PONCE, J.; VOS, R.; ROSERO, J.; CASTILLO, R. Is Latin America's Rise of the Middle Classes Lasting or Temporary? Evidence from Ecuador. In: VIVARES, E.(ed.). Regionalism, Development and the Post-Commodities Boom in South America. New York: Palgrave Macmillan, 2018. p. $25-46$

PONTÓN, D. Drogas, globalización y castigo: Una aproximación a la gobernanza policial contra las drogas en Ecuador 2011-2016. Cuyo, 2018. Tesis doctoral. Facultad de Ciencias Politicas y Sociales. Universidad Nacional de Cuyo.

PONTÓN, D.; GUAYASAMIN, T. Organized Crime, Security and Regionalism: The Governance of TOC in LA. In: VIVARES, E.(ed.). Regionalism, Development and the Post-Commodities Boom in South America. New York: Palgrave Macmillan, 2018. p. 270-290.

POLANYI, K. The Great Transformation: The Political and Economic Origins of Our Time. Boston: Beacon Press, 2001.

PRIETO, G. The Constructivist Political Economy of Regionalism in South America. In: VIVARES, E. (ed.). Handbook of International Political Economy. New York: Routledge, 2020.

QUILICONI, C.; KINGAH, S.; SOKO, M. BRICS Leadership at the Regional and Global Level: Disposition, Capacity and Legitimacy in a Multipolar Era. London/New York: Springer, 2015.

QUILICONI, C.; SALGADO, R. The South American Regionalisms: A shift or the Return of Economic Integration. In: VIVARES, E.(ed.). Regionalism, Development and the Post-Commodities Boom in South America. New York: Palgrave Macmillan, 2018. p. 291-307.

RABELLO DE CASTRO, P.; RONCI, M.; DORNBUSCH, R.; EDWARDS, S. (eds.) The Macroeconomics of Populism in Latin America. Chicago: University of Chicago Press, 1991. p. 1551-174.

RAVENHILL, J. Global Political Economy. Oxford: Oxford University Press, 2017.

RAVENHILL, J. Global Political Economy. Oxford: Oxford University Press, 2005.

RAVENHILL, J. International Political Economy. In: RHODES; R.A.W. (ed.). The Australian Study of Politics. Houndmills: Palgrave MacMillan, 2009, p. 293-301.

RETTBERG, A.; LEITERITZ, R.; NASI, C. (comp.) Diferentes recursos, conflictos diferentes: La economía política del conflicto armado y la criminalidad en las regiones de Colombia. Bogotá: Ediciones Uniandes, 2018.

RIVERA, F.; PONTÓN, D. Microtráfico en Quito, rutas, mercados y actores 2000-2012. Quito, Ecuador: Flacso Ecuador : IDR-CRDI : Relasedor, 2016. Disponível em: http://www.flacsoandes.edu.ec/libros?avanzado $=0$ \&query $=$ microtrafico. Accessed: 15 mar. 2018

RIGGIROZZI, P.; TUSSIE, D. The Rise of Post-hegemonic Regionalism: The Case of Latin America. London/New York: Springer, 2012.

RODRIGUEZ, F. Chinese finance and its effects on unequal development in Latin America, 2019. (forthcoming).

ROJAS, C. Acts of Indigenship: Historical struggles for equality and colonial difference in Bolivia. Citizenship Studies, v. 17, n. 5, p. 581-595, 2013 
SAGUIER, M.; GIOTTO, L. Las empresas transnacionales: un punto de encuentro para la Economía Política Internacional de América Latina. Revista Desafios, Bogotá, v. 30, n. 2, p. 159-190, 2018.

SALGADO, R.; VIVARES, E. The state of methodology in teaching, research and publishing in Latin American International Studies. In: CONGRESO DE LA RED CIPRI, 4., 2019, Quito-Ecuador. Working paper. Quito: CIPRI, 2019. https://www.flacsoandes.edu.ec/node/63099

SANAHUJA, A. La construcción de una región: Suramérica y el regionalismo posliberal. Una región en construcción. UNASUR y la integración en América del Sur. Madrid: Fundación CIDOB, 2010. p. 87-136.

SASSEN, S. The Global City: Introducing a Concept. The Brown Journal of World Affairs, v. 11, n. 2 , p. $27-44,2005$

SAUTÚ, R.; BONIOLO, P.; DALLE, P.; ELBERT, R. Manual de metodología. Construcción del marco teórico, formulación de los objetivos y elección de la metodología. Buenos Aires: CLACSO, 2005

SEABROOK, L.; YOUNG, K. The networks and niches of international political economy. Review of International Political Economy, v. 24, n. 2, p. 288-331, 2017.

SHAW, T.; MAHRENBACH, L.; MODI, R.; YI-CHONG, X. The Palgrave Handbook of Contemporary International Political Economy. New York: Palgrave Macmillan, 2019.

STANLEY, L.; FERNÁNDEZ, A. The Changing Problem of Regional Development Finance in Latin America. In: VIVARES, E.(ed.). Regionalism, Development and the Post-Commodities Boom in South America. New York: Palgrave Macmillan, 2018. p. 101-120.

STRANGE, S. Wake up, Krasner! The World Has Changed. Review of International Political Economy, v. 1, n. 2, p. 209-219, 1994.

STURZENEGGER, F. Currency Substitution and the Regressivity of Inflationary Taxation. Revista de Análisis Económico, v. 7, n. 1, p. 177-192, 1992.

SVAMPA, M. Consenso de los Commodities y lenguajes de valoración en Latín América. Revista Nueva Sociedad, n. 244, p. 30-46, 2013.

TAYLOR, I. The Logic of Disorder: 'Malignant Regionalization' in Central Africa. In: BØÅS, M.; MARCHAND; M.H.; SHAW, T. (ed.). The Political Economy of Regions and Regionalisms. Hampshire: Palgrave, 2005.

TICKNER, A. Hearing Latin American voices in International Relations Studies. International Studies Perspectives, v. 4, n. 4, p. 325-350, 2003.

THORP, R. A Historical Perspective on the Political Economy of Inequality in Latin America. In: SANTISO, J.; DAYTON-JOHNSON, J. (eds.). Latin American Political Economy. New York: Oxford University Press, 2012. p. 149-167.

TROWNSELL, T.; QUEREJAZU ESCOBARI, A.; SHANI, G.; CHADHA BEHERA, N.; REDDEKOP, J.; TICKNER, A. Recrafting International Relations through Relationality. E-International Relations, 2019.

TUSSIE, D. Rutas, Debates y Desafios de la Construcción del Campo de la Economía Política Internacional en América Latina. Flacso - Argentina, 2018.

TUSSIE, D. The tailoring of IPE in Latin America: lost, misfit, or misperceived? In: VIVARES, E. (ed.). Handbook of International Political Economy. New York: Routledge, 2020. 